\title{
Efek Perendaman Ikan Patin Siam (Pangasionodon hypophthalmus) dalam Larutan Vaksin HydroVac terhadap Diferensiasi Leukosit
}

\author{
Effects of Immersion Striped Catfish (Pangasionodon hypophthalmus) in HydroVac \\ Vaccine Solution for Leukocyte Differentation
}

\author{
Rabil Yusuf $^{1 *}$, Morina Riauwaty ${ }^{1}$, Henni Syawal ${ }^{1}$ \\ ${ }^{1}$ Jurusan Budidaya Perairan, Fakultas Perikanan dan Kelautan Universitas Riau \\ email:rabilyusuf78@gmail.com
}

(Received: 05 Juni 2021; Accepted: 28 Juni 2021)

\begin{abstract}
ABSTRAK
Vaksinasi merupakan salah satu cara untuk meningkatkan respon imun spesifik ikan terhadap suatu penyakit. Tujuan penelitian adalah mendapatkan lama waktu perendaman ikan dalam larutan vaksin HydroVac yang optimal dalam meningkatkan respons imun spesifik ikan patin siam dilihat dari total leukosit, diferensiasi leukosit dan aktivitas fagositosis. Penelitian ini menggunakan metode eksperimen dengan Rancangan Acak Lengkap (RAL) satu faktor dengan lima taraf perlakuan, adapun perlakuan pada penelitian adalah: Kn (tanpa perendaman vaksin HydroVac dan tanpa diinfeksi bakteri Aeromonas hydrophila), Kp (tanpa perendaman vaksin HydroVac dan diinfeksi bakteri A. hydrophila), P1 (Perendaman vaksin HydroVac selama 15 menit), P2 (Perendaman selama 30 menit), dan P3 (Perendaman selama 45 menit), serta diujitantang bakteri $A$. hydrophila). Hasil penelitian menunjukkan bahwa Perendaman dengan vaksin HydroVac dapat meningkatkan respons imun non-spesifik ikan patin siam yang terinfeksi bakteri A.hydrophila. Waktu perendaman selama 30 menit merupakan hasil terbaik untuk meningkatkan respons imunitas ikan patin siam yang terinfeksi bakteri A. hydrophila dilihat dari hasil total leukosit $9,12 \times 10^{4}$ $\mathrm{sel} / \mathrm{mm}^{3}$, kadar leukokrit 1,67\%, diferensiasi leukosit (limfosit 82,33\%, monosit 8,67\% dan neutrofil 9,00\%), nilai aktivitas fagositosis $34,67 \%$, dan tingkat perlindungan relatif $83,33 \%$.
\end{abstract}

Kata Kunci: Pangasionodon hypophthalmus, Vaksin Hydrovac, Leukosit, Perendaman

\begin{abstract}
Vaccination is one way to increase the specific immune response of fish to a disease. The aim of this research was to obtain the optimal immersion time of fish in the HydroVac vaccine solution in increasing the specific immune response of striped catfish seen from the total leukocytes, leucocyte differentiation and phagocytic activity. This study used an experimental method with a one-factor completely randomized design (CRD) with five levels of treatment, while the treatments in this study were: Kn (without immersion of HydroVac vaccine and without infection with Aeromonas hydrophila bacteria), Kp (without immersion of HydroVac vaccine and infected with bacteria A hydrophila), P1 (Immersion of HydroVac vaccine for 15 minutes), P2 (Immersion for 30 minutes), and P3 (Immersion for 45 minutes), and challenge against A.hydrophila bacteria. The results showed that immersion with the HydroVac vaccine could increase the non-specific immune response of striped catfish infected with A.hydrophila bacteria. Immersion time for 30 minutes is the best result to increase the immune response of striped catfish infected with $A$. hydrophila bacteria, seen from the total leukocyte results of $9,12 \times 104$ cells / $\mathrm{mm}^{3}$, leukocrit levels $1.67 \%$, leucocyte differentiation (lymphocyte $82.33 \%$ ), monocytes $8.67 \%$ and neutrophils $9.00 \%$ ), the value of phagocytosis activity was $34.67 \%$, and the relative protection level was $83.33 \%$.
\end{abstract}

Keyword: Pangasionodon hypophthalmus, HydroVac vaccine, Leukocytes, Immersion

\section{Pendahuluan}

Ikan patin siam merupakan ikan yang banyak dibudidayakan di Indonesia dan digemari oleh masyarakat khususnya di daerah Riau. Ikan patin siam adalah salah satu ikan air tawar yang cukup potensial dan 
memiliki nilai ekonomis yang besar dalam kegiatan budidaya dan terus berkembang seiring dengan permintaan pasar yang terus meningkat. Dengan semakin meningkatnya permintaan pasar maka para pembudidaya ikan jambal siam dituntut untuk memenuhi permintaan pasar sehingga produksi harus ditingkatkan.

Kendala yang dihadapi dalam usaha budidaya ikan air tawar khususnya patin siam adalah adanya serangan penyakit bakterial seperti Aeromonas hydrophila. Bakteri ini adalah penyebab penyakit haemorrhagic septicaemia yang juga disebut sebagai MAS (Motile Aeromonas Septicaemia). Kemampuan menimbulkan penyakit dari bakteri A.hydrophila cukup tinggi (Afrianto $e t$ al., 2015). Patogenitas A.hydrophila dapat menimbulkan mortalitas pada ikan budidaya hingga $80-100 \%$ dalam waktu 1-2 minggu (Thiyagarajan et al., 2014; Nahar et al., 2016).

Pencegahan penyakit ikan pada akuakultur telah sering dilakukan dengan menggunakan berbagai antibiotik. Penggunaan antibiotik secara terus menerus dapat menyebabkan bakteri patogen menjadi resisten, terjadi residu di dalam tubuh ikan dan lingkungan perairan yang akhirnya berbahaya bagi konsumen yang mengkonsumsinya (Lukistyowati dan Syawal, 2013; Sari et al., 2013). Untuk menghindari dampak penggunaan bahan kimia dan antibiotik, penanggulangan penyakit dapat diupayakan melalui peningkatan kekebalan melalui vaksinasi. Metode vaksinasi telah diterapkan pada beberapa jenis ikan, diantaranya mas (Cyprinus carpio) dengan vaksin inaktif A. salmonicida (Sari et al., 2013), nila (Oreochromis niloticus) dengan vaksin Post-Cooktail (Sukenda et al., 2017), jambal siam dengan vaksin HydroVac (Sinaga et al., 2019; Siregar et al., 2020).

Sumiati et al. (2019), pengaplikasian vaksin HydroVac pada ikan lele yang terinfeksi A. hydrophila mampu meningkatkan kelulushidupan mencapai $60 \%$ dibandingkan dengan ikan tanpa vaksinasi sebesar $31 \%$. Berdasarkan uraian di atas maka penulis tertarik melakukan penelitian tentang "Efek lama perendaman vaksin HydroVac terhadap diferensiasi leukosit ikan patin siam (P.hypophthalmus)".

Tujuan penelitian ini adalah untuk mendapatkan waktu perendaman ikan dalam larutan vaksin HydroVac yang optimal dalam meningkatkan respons imun ikan patin siam dilihat dari total leukosit, diferensiasi leukosit dan indeks fagositosis.

\section{Metode Penelitian}

\subsection{Waktu dan Tempat}

Penelitian ini telah dilaksanakan pada bulan Oktober - April 2019 di Laboratorium Parasit dan Penyakit Ikan, Fakultas Perikanan dan Kelautan Universitas Riau.

\subsection{Metode Penelitian}

Metode yang digunakan dalam penelitian ini adalah metode eksperimen dengan Rancangan Acak Lengkap (RAL) satu faktor dengan lima taraf perlakuan, untuk mengurangi tingkat kekeliruan maka dilakukan ulangan sebanyak tiga kali sehingga diperlukan 15 unit percobaan. Penentuan dosis perendaman ikan uji menggunakan vaksin HydroVac mengacu pada Andriyanto dan Sugiani (2015). Masing-masing perlakuan yang digunakan adalah:

$\mathrm{Kn}=$ Kontrol negatif (tanpa perendaman vaksin HydroVac dan tanpa diinfeksi bakteri A.hydrophila).

$\mathrm{Kp}=$ Kontrol positif (tanpa perendaman vaksin HydroVac dan diinfeksi bakteri A.hydrophila).

$\mathrm{P} 1=$ Perendaman dalam larutan vaksin HydroVac $1 \mathrm{~mL} / 10 \mathrm{~L}$ air selama 15 menit.

$\mathrm{P} 2=$ Perendaman dalam larutan vaksin HydroVac $1 \mathrm{~mL} / 10 \mathrm{~L}$ air selama 30 menit.

P3 = Perendaman dalam larutan vaksin HydroVac $1 \mathrm{~mL} / 10 \mathrm{~L}$ air selama 45 menit.

\subsection{Prosedur Penelitian}

\subsubsection{Persiapan Wadah dan Ikan Uji}

Wadah pemeliharaan yang digunakan adalah akuarium berukuran 40 × 30 × $30 \mathrm{~cm}$ sebanyak 15 buah. Bak fiber volume 80 liter sebanyak 5 (lima) buah untuk wadah aklimatisasi ikan uji. Sebelum digunakan, akuarium dan bak fiber terlebih dahulu dibersihkan dan diisi air sampai penuh lalu diberi larutan $\mathrm{KMnO}_{4}$ (Kalium Permanganat) sebanyak 25 ppm dan diberi aerasi selama 24 jam dengan tujuan akuarium dan bak fiber steril dari mikroorganisme patogen. 
Air yang digunakan berasal dari sumur bor yang telah diendapkan dalam tangki. Masing-masing akuarium diisi air dengan volume 30 liter, dan masing-masing bak fiber diisi air dengan volume 80 liter. Ikan uji dilakukan dengan mengambil ikan sebanyak 250 ekor dari BBI Sei Tibun Kabupaten Kampar

\subsubsection{Perendaman dalam Vaksin HydroVac dan Pemeliharaan Ikan}

Vaksin HydroVac yang digunakan berasal dari PT Sanbe. Pemberian vaksin dilakukan pada wadah yang berukuran 15 liter sebanyak sembilan buah, masing-masing toples diberi label $\mathrm{P}_{1}, \mathrm{P}_{2}, \mathrm{P}_{3}$. Masing-masing wadah diisi air sebanyak 10 liter, kemudian dimasukan vaksin ke dalam air dengan dosis 1 $\mathrm{mL} / 10 \mathrm{~L}$, dimana $P_{1}$ direndam selama 15 menit, $\mathrm{P}_{2}$ direndam selama 30 menit, $\mathrm{P}_{3}$ direndam selama 45 menit. Setiap perlakuan diisi ikan uji sebanyak 10 ekor/ 30 L air dan diberi aerasi. Setelah dilakukan vaksinasi ikan dikembalikan ke dalam akuarium.

Pemiliharaan ikan dilakukan selama tiga minggu, ikan diberi pakan secara adlibitum menggunakan pelet komersial dengan frekuensi tiga kali sehari, yaitu pada pukul $08.00,12.00$, dan 16.00 WIB. Setiap dua hari sekali pada pagi hari digunakan penyiponan.

\subsubsection{Uji Tantang}

Isolat A. hydrophila berasal dari Laboratorium Parasit dan Penyakit Ikan Fakultas Perikanan dan Kelautan Universitas Riau. uji tantang dilakukan pada hari ke-22 dengan cara menginfeksikan $A$. hydrophila secara intramuscular sebanyak $0,1 \mathrm{~mL} /$ ekor dengan kepadatan bakteri $10^{8} \mathrm{CFU} / \mathrm{mL}$. Pada masa uji tantang, ikan uji tetap diberi pakan dan dilakukan penyiponan. Pemeliharaan pasca uji tantang dilakukan selama 14 hari.

\subsubsection{Pengambilan Darah Ikan}

Pengambilan darah ikan uji dilakukan sebanyak tiga kali, yaitu pada awal pemeliharaan sebelum diberi perlakuan (H-0), kedua setelah tiga minggu pemeliharaan $(\mathrm{H}-$ 21) dan yang ketiga setelah 14 hari pasca uji tantang dengan bakteri A. hydrophila (H-36). Sebelum mengambil darah, ikan dibius dalam larutan minyak cengkeh dengan dosis 0,1 $\mathrm{mL} / \mathrm{L}$. Syirenge dan tabung eppendorf dibilas terlebih dahulu dengan antikoagulan, yaitu
EDTA $10 \%$. Darah ikan diambil dari bagian linea lateralis arah caudal dengan menggunakan syirenge $1 \mathrm{~mL}$, darah yang telah diambil dimasukkan ke dalam tabung eppendorf yang telah dibasahi dengan antikoagulan dan selanjutnya digunakan untuk perhitungan total leukosit, diferensiasi leukosit, dan Aktivitas fagositosis.

\subsection{Parameter yang Diamati}

\subsubsection{Tingkat Perlindungan Relatif}

Menurut Nitimulyo et al. (2005), tingkat perlindungan relatif dapat dihitung dengan rumus sebagai berikut:

$\mathrm{RPS}=\left[1-\frac{\% \text { kematian ikan divaksin }}{\% \text { kematian ikan yang tidak divaksin }}\right]$ X100\%

\subsubsection{Total Leukosit}

Prosedur perhitungan total leukosit mengacu pada Blaxhall dan Daisley (1973) dalam Iman et al. (2016), yaitu dengan cara sampel darah dihisap dari mikrotube dengan menggunakan pipet leukosit hingga skala 0,5 dan ditambah larutan Turk hingga garis 11, setelah itu dihomogenkan dengan cara menggoyang-goyangkan pipet leukosit membentuk angka delapan selama lima menit. Setelah homogen, darah dibuang sebanyak dua tetes untuk menghilangkan udara, lalu darah diteteskan pada kotak haemocytometer dan ditutup dengan cover glass. Selanjutnya diamati di bawah mikroskop dengan pembesaran 10x40. Jumlah total leukosit dihitung dengan menggunakan mikroskop pada 4 kotak besar haemocytometer dengan rumus sebagai berikut :

\section{Keterangan :}

$$
\sum \text { Leukosit }=\sum \text { n } \times 50 \mathrm{sel} / \mathrm{mm}^{3}
$$

$\sum \mathrm{n}=$ Jumlah total leukosit pada 4 kotak besar

$50=$ Faktor pengenceran

\subsubsection{Diferensiasi Leukosit}

Perhitungan jenis leukosit berdasarkan metode Blaxhall dan Daisley (1973) dalam Kurniawan et al. (2020), yaitu dengan cara mengambil darah ikan, kemudian dibuat preparat ulas darah pada objek glass lalu dikering anginkan, selanjutnya difiksasi dengan larutan methanol selama 5 menit, setelah itu dibilas dengan akuades lalu dikeringanginkan, dan dilanjutkan dengan 
pewarnaan giemsa selama 20 menit, setelah itu dicuci dengan air mengalir, kemudian dikeringanginkan, lalu diamati di bawah mikroskop dengan pembesaran 10x40. Jenis leukosit yang diamati adalah limfosit, monosit, dan neutrofil. Kemudian diferensiasi leukosit dihitung dengan rumus sebagai berikut:

\section{Persentase sel $=\sum$ jumlah sel $\times 100 \%$}

\subsection{Analisis Data}

Data yang diperoleh selama penelitian disajikan dalam bentuk tabel kemudian dihitung. Selanjutnya data dianalisa secara statistik menggunakan software IBM SPSS versi 22.
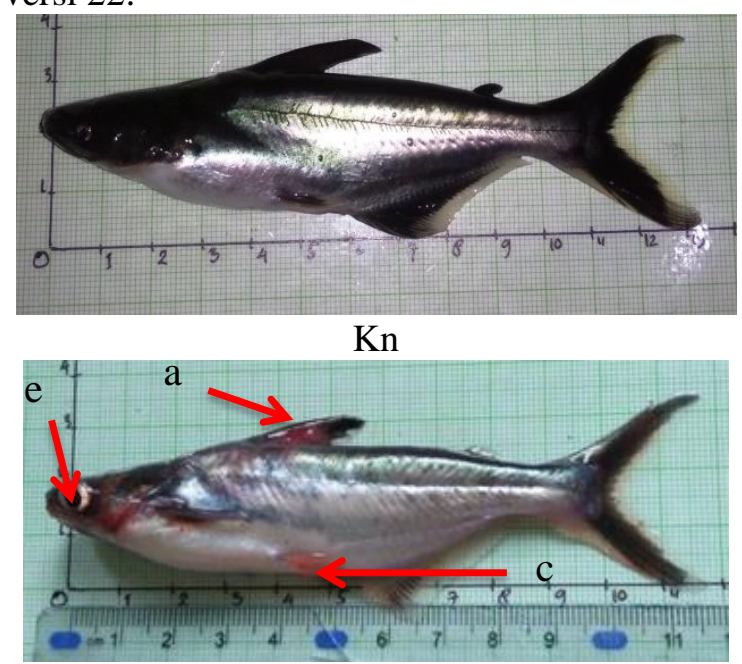

P1
3. Hasil dan Pembahasan

3.1. Gejala Klinis Ikan Patin Siam yang Terinfeksi Bakteri A. hydrophila

Ikan patin siam yang terinfeksi bakteri $A$. hydrophila menunjukkan perubahan gejala klinis setelah 24 jam, seperti terjadinya exopthalmia (mata membengkak), hemoragi (pendarahan), dropsy (perut membengkak), ulcer (luka) dan sirip geripis. Ikan yang terinfeksi bakteri A.hydrophila memiliki gejala klinis seperti exopthalmia, dropsy, hemoragi, (Rosidah et al., 2018) dan geripis (Tamba et al., 2021). Adapun gejala klinis yang terlihat setelah 24 jam pascauji tantang dapat dilihat pada Gambar 1.
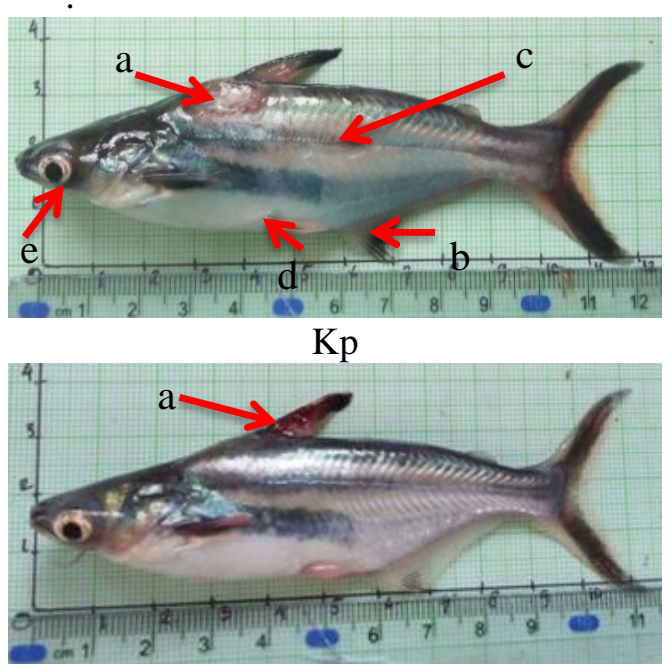

P2

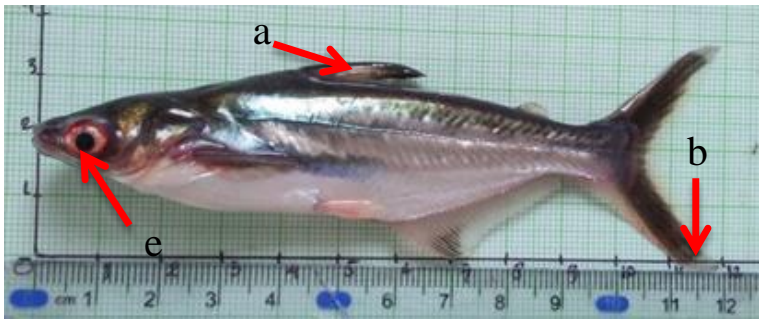

P3

Gambar 1. Gejala Klinis Ikan Patin Siam (P. hypophthalmus) yang terinfeksi A.hydrophila

Keterangan: a) Ulcer, b) sirip geripis, c) hemoragi, d) dropsy, e) exopthalmia. Kn: Kontrol negatif (tanpa pemberian vaksin dan tanpa uji tantang A. hydrophila), Kp: Kontrol positif (tanpa pemberian vaksin dan diuji tantang $A$. hydrophila $), \mathrm{P}_{1}$ : Benih jambal siam direndam dalam larutan vaksin $1 \mathrm{~mL} / 10 \mathrm{~L}$ air selama 15 menit, $\mathrm{P}_{2}$ : Benih jambal siam direndam dalam larutan vaksin $1 \mathrm{~mL} /$ $10 \mathrm{~L}$ air selama 30 menit, $\mathrm{P}_{3}$ : Benih jambal siam direndam dalam larutan vaksin $1 \mathrm{~mL} / 10 \mathrm{~L}$ air selama 45 menit

Gejala klinis pada $\mathrm{P}_{1}$ setelah 24 jam pasca uji tantang menunjukkan terjadinya ulcer (luka), exopthalmia (mata membengkak), dan hemoragi (pendarahan). Sedangkan pada $\mathrm{P}_{3}$ pasca uji tantang menunjukkan terjadinya ulcer, sirip geripis dan hemoragi. Ulcer (luka) yang terjadi disebabkan oleh tingginya kepadatan bakteri pada bekas suntikan, sehingga volume dan intensitas toksin yang dihasilkan ketika proses infeksi juga lebih tinggi. Selanjutnya hemoragi (pendarahan) yang terjadi diduga disebabkan oleh enzim yang hemolisin yan dihasilkan oleh bakteri $A$. hydrophila yang 
memecah sel darah merah sehingga menimbulkan warna kemeraha pada permukaan kulit. Menurut Triyaningsih et al. (2014) hemolisin yang terlarut dalam darah lebih lanjut mampu melisiskan sel darah merah dan membebaskan hemoglobinnya sehingga darah banyak yang keluar melewati luka pada permukaan tubuh yang terinfeksi. Hal ini menyebabkan terjadinya haemoragi.

Bakteri A.hydrophila dapat mengenali dan berikatan dengan sel reseptor pada se-sel tertentu dan mengurai sel inang dengan memproduksi enzim-enzim ekstraseluler seperti hemolisin, protease dan elastase sehingga menyebabkan inflamasi, peradangan dan berkembang menjadi borok. Ulser (tukak) yang terbentuk karena aktivitas proteolitik dari bakteri, dimana keadaan ini mungkin dikarenakan adanya substansi produk ekstraseluler bakteri seperti protease dan sitokin yang menghidrolisis dan melisiskan jaringan inang (Newman, 1982). Menurut Wibawa (2010), bahwa vaksin HydroVac mampu meningkatkan sistem imunitas ikan terhadap serangan bakteri A. hydrophila.

Perendaman ikan dalam larutan vaksin HydroVac selama 30 menit memberikan peningkatan imunitas yang optimal bagi ikan patin siam, hal ini menunjukkan lama perendaman mempengaruhi jumlah vaksin yang masuk ke dalam tubuh ikan dan tingkat stres ikan. Lama perendaman juga mampu menyebabkan ikan menjadi stress (Syawal dan Siregar, 2010), menyebabkan organ kekebalan berkurangnya mekanisme resistensi terhadap antigen dan menghalangi antigen masuk ke dalam sistem sirkulasi darah, sehingga menyebabkan menurunya fungsi imun (Du et al., 2017).

\subsection{Total Leukosit}

Total leukosit ikan patin siam setelah perendaman vaksin HydroVac berkisar antara $7,57-8,54 \times 10^{4} \mathrm{sel} / \mathrm{mm}^{3}$. Sedangkan pasca uji tantang total leukosit berkisar antara 8,15-9,12 x $10^{4} \mathrm{sel} / \mathrm{mm}^{3}$ Lebih jelas dapat dilihat pada Tabel 1 .

Tabel 1. Total Leukosit Ikan Patin Siam Selama Penelitian

\begin{tabular}{|c|c|c|c|}
\hline \multirow{2}{*}{ Perlakuan } & \multicolumn{3}{|c|}{ Total Leukosit $\left(\times 10^{4} \mathrm{sel} / \mathrm{mm}^{3}\right)$} \\
\hline & Awal (H-0) & Hari ke 21 pasca vaksinasi & Hari ke 14 pasca ujitantang \\
\hline $\mathrm{Kn}$ & $7,21 \pm 0,11$ & $7,32 \pm 0,04^{\mathrm{b}}$ & $7,21 \pm 0,04^{\mathrm{b}}$ \\
\hline Kp & $7,21 \pm 0,11$ & $7,13 \pm 0,10^{\mathrm{a}}$ & $0,00 \pm 0,00^{\mathrm{a}}$ \\
\hline P1 & $7,21 \pm 0,11$ & $7,57 \pm 0,09^{c}$ & $8,15 \pm 0,07^{\mathrm{c}}$ \\
\hline P2 & $7,21 \pm 0,11$ & $8,54 \pm 0,12^{\mathrm{e}}$ & $9,12 \pm 0,03^{\mathrm{e}}$ \\
\hline $\mathrm{P} 3$ & $7,21 \pm 0,11$ & $8,07 \pm 0,05^{\mathrm{d}}$ & $8,55 \pm 0,06^{\mathrm{d}}$ \\
\hline
\end{tabular}

Tabel 1 menunjukkan bahwa terjadi peningkatan nilai total leukosit pada ikan patin siam setelah perendaman vaksin HydroVac, berkisar antara 7,57-8,54 x $10^{4}$ $\mathrm{sel} / \mathrm{mm}^{3}$, jika dibandingkan dengan ikan patin siam normal $(\mathrm{Kn}$ dan $\mathrm{Kp})$ berkisar antara $7,13-7,32 \times 10^{4} \mathrm{sel} / \mathrm{mm}^{3}$. Hal ini menunjukkan bahwa pemberian vaksin dapat menstimulasi pembentukkan sistem imun. Total leukosit tertinggi terdapat pada $\mathrm{P} 2$, yaitu $8,54 \times 10^{4}$ $\mathrm{sel} / \mathrm{mm}^{3}$ dan masih berada pada kisaran normal. Menurut Phu et al. (2016), total leukosit ikan patin normal berkisar antara $6,95-11,9 \times 10^{4} \mathrm{sel} / \mathrm{mm}^{3}$.

Total leukosit pasca uji tantang dengan bakteri A. hydrophila menunjukkan adanya peningkatan pada ikan patin siam yang diberikan vaksin berkisar antara 8,15-8,55 $\mathrm{x}$ $10^{4} \mathrm{sel} / \mathrm{mm}^{3}$, jika dibandingkan dengan ikan patin siam normal $(\mathrm{Kn})$, yaitu $7,20 \times 10^{4}$ $\mathrm{sel} / \mathrm{mm}^{3}$. Sedangkan pada perlakuan Kp ikan mengalami mortalitas sebesar $100 \%$ pasca uji tantang dengan bakteri A. hydrophila. Total leukosit tertinggi ikan patin siam pada $\mathrm{P} 2$, yaitu $9,12 \times 10^{4} \mathrm{sel} / \mathrm{mm}^{3}$ dan masih berada kisaran normal. Menurut Iman et al. (2017), total leukosit ikan jambal siam berkisar antara $7,82-12,15 \times 10^{4} \mathrm{sel} / \mathrm{mm}^{3}$, sedangkan Lestari et al. (2021), total leukosit ikan jambal siam berkisar antara 7,19-10,26 sx 10 $0^{4} \mathrm{sel} / \mathrm{mm}^{3}$

Perendaman ikan patin dalam larutan vaksin HydroVac memberikan peningkatan total leukosit, sebagai respon terhadap antigen yang masuk ke dalam tubuh ikan. Jumah leukosit yang meningkat pascavaksinasi dan pascauji tantang menunjukkan sistem pertahanan tubuh merespon adanya antigen yang masuk ke dalam tubuh sebagai upaya pertahanan tubuh. Hal ini sesuai dengan pernyataan Kresno dalam Utami et al. (2013), 
bahwa peningkatan sel leukosit merupakan refleksi keberhasilan sistem imunitas ikan dalam mengembangkan respons imunitas seluler sebagai pemicu untuk respons kekebalan.

Menurut Sukenda et al. (2014), tubuh ikan membaca bahwa vaksin yang masuk dianggap sebagai antigen. Tubuh memberi respon dengan memproduksi leukosit. Selain itu tubuh juga memberi respons dengan membentuk antibodi. Martins et al. (2008) menyatakan bahwa jumlah leukosit pada ikan yang terinfeksi patogen akan meningkat sebagai upaya pertahanan tubuh. Pada akhir pengamatan, jumlah leukosit masih cukup tinggi pada beberapa perlakuan. Hal tersebut menunjukkan tubuh masih memberikan perlawanan terhadap infeksi bakteri.

Fluktuasi total leukosit pada tiap perlakuan dipengaruhi oleh kondisi tertentu seperti; stres, umur, bobot dan aktivitas fisiologis. Ikan dewasa tentunya memiliki sistem pertahanan tubuh lebih kuat dibandingkan larva atau juvenil. Selain itu juga dipengaruhi oleh kemampuan ikan untuk merespon antigen (benda asing) yang masuk. Menurut Anderson (1992), respon kekebalan non spesifik dan spesifik dipengaruhi oleh beberapa faktor, salah satunya ialah imunosupresi. Imunosupresi disebabkan oleh dosis yang terlalu rendah atau tinggi, sehingga tubuh ikan tidak mampu merespon rangsangan antigenik yang masuk ke dalam tubuh ikan.

\subsection{Diferensiasi Leukosit Ikan Patin Siam}

Perhitungan diferensiasi leukosit dilakukan untuk melihat perubahan jumlah dari jenis leukosit (limfosit, monosit dan neutrophil). Perendaman ikan patin siam menggunakan vaksin HydroVac memberikan pengaruh pada tiap perlakuannya terhadap diferensiasi leukosit $(\mathrm{p}<0,05)$. Hasil pengamatan diferensiasi leukosit ikan patin siam selama penelitian dapat dilihat pada Tabel 2.

\section{Tabel 2. Diferensiasi Leukosit pada Ikan Patin Siam selama Penelitian}

\begin{tabular}{ccccc}
\hline Diferensiasi Leukosit & Perlakuan & Limfosit & Monosit & Neutrofil \\
\hline & Kn & $78,33 \pm 0,58^{\mathrm{a}}$ & $9,67 \pm 0,58^{\mathrm{ab}}$ & $12,00 \pm 1,00^{\mathrm{b}}$ \\
Hari ke-21 pasca & Kp & $78,67 \pm 0,58^{\mathrm{a}}$ & $9,67 \pm 0,58^{\mathrm{ab}}$ & $11,67 \pm 0,58^{\mathrm{b}}$ \\
vaksinasi & P1 & $80,00 \pm 1,00^{\mathrm{b}}$ & $10,33 \pm 0,58^{\mathrm{b}}$ & $9,67 \pm 0,58^{\mathrm{a}}$ \\
& P2 & $83,33 \pm 0,58^{\mathrm{d}}$ & $8,33 \pm 0,58^{\mathrm{a}}$ & $8,33 \pm 0,58^{\mathrm{a}}$ \\
& $\mathrm{P} 3$ & $81,33 \pm 0,58^{\mathrm{c}}$ & $9,33 \pm 0,58^{\mathrm{ab}}$ & $9,33 \pm 0,58^{\mathrm{a}}$ \\
\hline & $\mathrm{Kn}$ & $78,33 \pm 0,58^{\mathrm{b}}$ & $10,00 \pm 1,00^{\mathrm{b}}$ & $11,67 \pm 0,58^{\mathrm{c}}$ \\
Hari ke-14 pasca & Kp & $0,00 \pm 0,00^{\mathrm{a}}$ & $0,00 \pm 0,00^{\mathrm{a}}$ & $0,00 \pm 0,58^{\mathrm{a}}$ \\
ujitantang & P1 & $79,00 \pm 1,00^{\mathrm{b}}$ & $9,67 \pm 0,58^{\mathrm{b}}$ & $10,33 \pm 0,58^{\mathrm{bc}}$ \\
& P2 & $82,33 \pm 0,58^{\mathrm{d}}$ & $8,67 \pm 0,58^{\mathrm{b}}$ & $9,00 \pm 1,00^{\mathrm{b}}$ \\
& P3 & $80,33 \pm 0,58^{\mathrm{c}}$ & $9,33 \pm 0,58^{\mathrm{b}}$ & $10,33 \pm 0,58^{\mathrm{bc}}$ \\
\hline
\end{tabular}

Keterangan : Superscript yang berbeda menunjukkan berbeda nyata $\mathrm{P}<0,05$

Pasca uji tantang jumlah limfosit ikan patin yang direndam menggunakan vaksin HydroVac berkisar antara 79,00-82,33\%, jumlah ini lebih tinggi jika dibandingkan dengan $\mathrm{Kn}(78,33 \%)$. Kadar limfosit pada Kp tidak dapat diamati, karena ikan mati $100 \%$ pasca uji tantang dengan bakteri A.hydrophila. hal ini menunjukkan bahwa perendaman ikan patin siam dalam larutan vaksin Hydrovac menstimulasi terbentuk limfosit sebagai respon imun, baik non specific maupun spesifik.

Jumlah limfosit pada ikan patin siam selama penelitian berada pada kisaran normal, sesuai pendapat Rahmadona et al. (2020), menyatakan bahwa jumlah limfosit ikan jambal siam berkisar antara 76,33-84,33\%. Sedangkan Kurniawan et al. (2020), menyatakan bahwa jumlah limfosit ikan patin berkisar 75,67-81,67\%. Peningkatan jumlah limfosit menandakan pemberian vaksin HydroVac menstimulus pembentukan antibodi dan menekan pertumbuhan bakteri A.hydrophila.

Pasca uji tantang limfosit mengalami penurunan karena intensitas infeksi sehingga peningkatan aktivitas perlawanan terhadap infeksi bakteri dan menyebabkan pengurangan sel limfosit. Rustikawati (2012) menyatakan bahwa adanya peningkatan intensitas infeksi oleh patogen tertentu akan memicu kebutuhan sel darah putih (monosit dan neutrofil) dan 
peningkatan kebutuhan tersebut akan mengakibatkan terjadinya pengurangan sel agen penyedia zat kebal tubuh yaitu limfosit.

Pasca uji tantang jumlah monosit dan neutrofil ikan patin yang direndam menggunakan vaksin HydroVac dengan lama peremdaman berbeda berkisar antara 8,67$9,67 \%$ dan 9,00-10,33\%, lebih rendah dibandingkan $\mathrm{Kn}(10,00 \%)$. Kp tidak dapat diamati karena ikan mengalami kematian sebesar $100 \%$ pasca uji tantang bakteri $A$. hydrophila. Hal ini menunjukkan penggunaan vaksin HydroVac mampu menekan pertumbuhan bakteri A. hydrophila pasca uji tantang.

Infeksi bakteri yang masuk dalam tubuh ikan pasca uji tantang akan merangsang sel darah putih untuk memproduksi monosit lebih banyak. Hal ini sesuai dengan penyataan Robert dalam Destriana (2011) yang menyatakan bahwa fungsi monosit sebagai agen makrofag yang memfagosit benda asing yang masuk ke dalam tubuh. Affandi dan Tang (2002) menambahkan bahwa pada saat terjadi infeksi oleh benda asing, maka monosit akan bergerak cepat meninggalkan pembuluh darah menuju daerah yang terinfeksi untuk melakukan fagositosis. Monosit memiliki kemampuan menembus dinding pembuluh kapiler, kemudian masuk ke jaringan dan berdiferensiasi menjadi makrofag.

Peningkatan jumlah neutrofil merupakan akibat dari mekanisme kekebalan tubuh yang bekerja sebagai respon adanya infeksi dalam tubuh. Menurut Tizard (1988), hal ini berkaitan dengan fungsi utama neutrofil yaitu penghancuran bahan asing melalui proses fagositosis yaitu kemotaksis dimana sel akan bermigrasi menuju partikel, pelekatan partikel pada sel, penelanan partikel oleh sel, dan penghancuran partikel oleh enzim lisosim di dalam fagolisosom. Peningkatan aktivitas pergerakan sel neutrofil disebabkan karena distimulasi oleh adanya vaksin HydroVac bersifat imunogenik, sehingga aktivitas produksi oleh organ pembentuk sel tersebut semakin meningkat. Hal ini sesuai dengan pendapat Fujaya (2004) bahwa keluarnya sel neutrofil dari pembuluh darah pada saat terjadinya infeksi disebabkan oleh adanya pengaruh rangsangan kimiawi eksternal atau kemotaksis diantaranya distimulasi oleh bahan vaksin.

\subsection{Tingkat Perlindungan Relatif Ikan Patin Siam \\ Tingkat perlindungan relatif ikan patin} siam yang diberikan perlakuan lama perendaman vaksin HydroVac berkisar antara 63,33-83,33\%, tingkat perlindungan relatif tertinggi terdapat pada perlakuan $\mathrm{P}_{2}$, yaitu sebesar $83,33 \%$, sedangkan yang terendah terdapat pada perlakuan $\mathrm{P}_{1}(63,33 \%)$, dan $\mathrm{P}_{3}$ $(66,66 \%)$ (Gambar 2). Perendaman ikan patin siam dalam larutan vaksin HydroVac selama 30 merupakan perlakuan yang optimal, karena memberikan tingkat perlindungan relatif sebesar 83\%. Menurut Mulia (2007) nilai RPS optimum apabila memberikan perlindungan relatif minimum $70 \%$

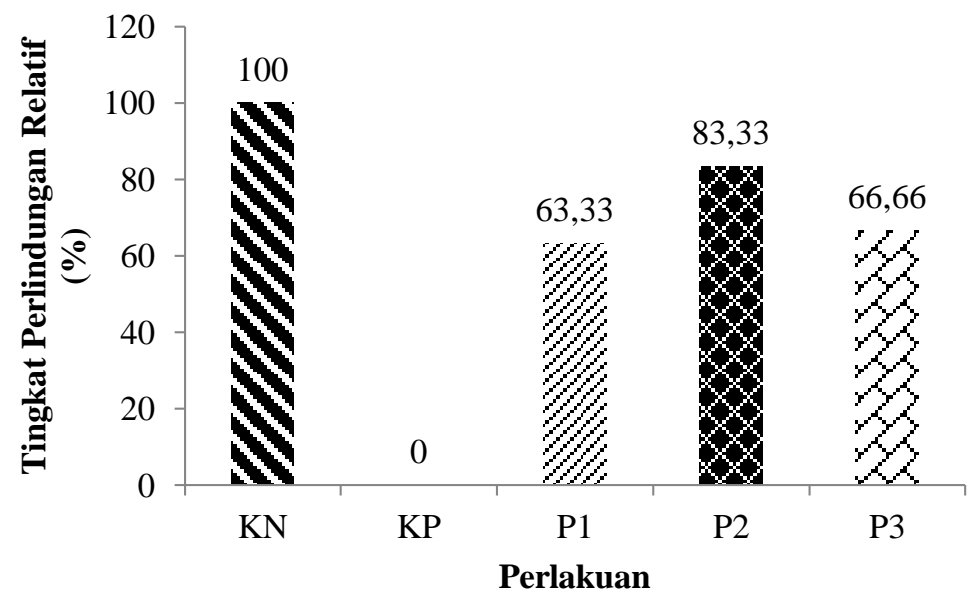

Gambar 2. Tingkat Perlindungan Relatif Ikan Patin Siam 


\section{Kesimpulan dan Saran}

Lama perendaman ikan patin siam dalam larutan vaksin HydroVac memberikan pengaruh terhadap diferensiasi leukosit $(\mathrm{P}<0,05)$. Perendaman ikan patin siam menggunakan vaksin HydroVac selama 30 menit merupakan waktu perendaman terbaik untuk meningkatkan respons imunitas ikan patin siam yang terinfeksi bakteri A.hydrophila, dilihat dari hasil total leukosit $9,12 \times 10^{4} \mathrm{sel} / \mathrm{mm}^{3}$, kadar leukokrit $1,67 \%$, diferensiasi leukosit (limfosit 82,33\%, monosit $8,67 \%$ dan neutrofil $9,00 \%$ ),dan tingkat perlindungan relatif $83,33 \%$.

Berdasarkan hasil penelitian, maka disarankan waktu perendaman selama 30 menit dalam pengaplikasian vaksin hydroVac pada ikan yang terinfeksi bakteri A. hyrophila. Untuk penelitian lanjut mengenai lama perendaman dan booster terhadap ikan patin siam yang terinfeksi bakteri A. hydrophila.

\section{Daftar Pustaka}

Affandi, R. dan U.M. Tang. (2002). Fisiologi Hewan Air. Universitas Riau Press. Riau. 217 hlm

Anderson, D.P. (1992). Immunostimulans, Adjuvants, and Vaccine Corries in Fish Aplication to Aquaculture. U.S. Fish and Wildlife Service. Kearneysville, West Virginia, USA.

Andriyanto, S., dan D. Sugiani. (2015). Performa Pertumbuhan Benih Ikan Lele (Clarias gariepinus) dengan Aplikasi Vaksin HydroVac. Meida Akuakultur, 10 (2): 59-64

Blaxhall, P.C., and K.W. Daisley. (1973). Routine Haematological Methods for use with Fish Blood. J. Fish Biology, 5:577-581

Destriana, Y. (2011). Uji Efektivitas Lidah Buaya (Aloe vera) Melalui Pakan Komersil Sebagai Imunostimulan pada Benih Lele Dumbo (Clarias gariepinus) terhadap Infeksi Bakteri Aeromonas hydrophila. Skripsi. Fakultas Perikanan dan Ilmu Kelautan. Universitas Padjadjaran. Bandung. 78 hlm.

Du, Y., X.Tang, X. Sheng, J. Xing, dan W. Zhan. (2017). The Influence of Concentration of Inactivated Edwardsiella tarda Bacterin and Immersion Time on Antigen Uptake and Expression of Immune-related
Genes in Japanese Flounder

(Paralichthys olivaceus). Microbial Pathogenesis, 103: 19-28

Fujaya, Y. (2004). Fisiologi Ikan Dasar Pengembangan Teknik Perikanan. Jakarta. Rineka Cipta. Hlm 53-60.

Iman, K.N., M. Riauwaty dan H. Syawal. (2017). Diferensiasi Leukosit Ikan Jambal Siam (Pangasius hypohthlamus) yang diberi Pakan dengan Penambahan Ekstrak Kurkumin dari Kunyit (Curcuma domestika). Jurnal Online Mahasiswa, 2(1): 1-14

Kurniawan, R., H. Syawal, dan I. Effendi. (2020). Pengaruh Penambahan Suplemen Herbal pada Pakan terhadap Diferensiasi Leukosit Ikan and Sintasan Ikan Patin (Pangasionodon hypophthalmus). Jurnal Akuakultur Rawa Indonesia, 8(2): 150-163

Lestari, J., H. Syawal, dan M. Riauwaty. (2021). Diferensiasi Leukosit Ikan Jambal Siam (Pangasionodon hypophthalmus) yang diberi Pakan Mengandung Jamu Fermentasi. Jurnal Ruaya, 9(1): 1-9

Lukistyowati I. dan H. Syawal. (2013). Potensi Pakan yang Mengandung Sambiloto (Andrographis paniculata) dan Daun Jambu Biji (Psidium guajava) untuk Menanggulangi Bakteri Aeromonas hydrophila pada Ikan Baung (Mystus nemurus). Jurnal Akuakultur Rawa Indonesia, 1(2):135 147.

Martins, Ml., J.L.P. Mouriño, G. Amaral, F. Vieira, G. Dotta, A. Jatobá, F. Pedrotti, G. Jerônimo, C. Buglione-Neto, dan G. Pereira-Jr. (2008). Haematological changes in Nile Tilapia Experimentally Infected with Enterococcus sp. Brazilian Journal of Biology, 68(3), 657-661.https://doi.org/10.1590/S151969842008000300025

Mulia, D.S. (2007). Keefektifan Vaksin Aeromonas hydrophila untuk Mengendalikan Penyakit Mas (Motile Aeromonas Septicemia) pada Gurami (Osphronemus gouramy Lac.). Jurnal Pembangunan Pedesaan, 7(1): 43-52

Nahar, S., M.M. Rahman., G.U. Ahmed, dan Md.A.R.Farok. (2016). Isolation, Identification, and Caracterization of Aeromonas hydrophila from Juvenile 
Farmed Pangasius (Pangasius hypophthalmus). International Journal of Fisheries and Aquatic Studies, 4(4) 52-60.

Newman. $\quad$ S.G. (1982). Aeromonas hydrophila: A review with emphasis on its role in fish diseases. In: D.P. Anderson, M. Dorson and PH. Dubourget (Eds). Les Antigens des Microorganismes pathogenes des poisson. Collection Fondation Marcel Merieux. pp 87-118

Nitimulyo, K.H., A. Isnansetyo, dan Triyanto. (2005). Efektivitas Vaksin Polivalen untuk Pengendalian Vibriosis pada Kerapu Tikus (Cromileptes altivelis). Jurnal Perikanan, 7(2): 95-100

Phu, T.M., N.T.K. Ha, D.T.M. Tien, T.S. Tuyen and D.T.T. Huong. (2016). Effect of Beta-Glucans on Hematological, Immunoglobulins and Stress Parameters of Striped Catfish (Pangasianodon hypophthalmus) Fingerling. Can Tho University Journal of Science, 4: 105-113

Rahmadona, Z., H. Syawal, I. Lukistyowati. (2020). Description of Leukocytes Pangasius hypophthalmus which is Fed with Extracts of Mangrove Leaf (Rhizophora apiculata) and Maintained in The Floating Cages. Jurnal Perikanan dan Kelautan. 25(1): 79-87

Rosidah., W. Lili, Iskandar, M.R. Afriliansyah. (2018). Efektivitas Ekstrak Daun Kersen untuk Pengobatan Benih Ikan Nila yang Terinfeksi Bakteri Aeromonas hydrophila. Jurnal Akuatika Indonesia, 3(1): 10-18

Rustikawati，I. (2012). Efektivitas Ekstrak Sargassum sp. terhadap Diferensiasi Leukosit Ikan Nila (Oreochromis niloticus) yang Diinfeksi Streptococcus iniae. Jurnal Akuatika, 3(2): 125-134

Sari, R.H., A. Setyawan, dan Suparmono. (2013). Peningaktan Imunogenisitas Vaksin Inaktif Aeromonas salmonicida dengan Penambahan Adjuvant pada Ikan mas (Cyprinus carpio). E-jurnal Rekayasa dan Teknologi Budidya Perairan, 1(2): 87-94

Sinaga, R. M. Riauwaty, dan H. Syawal. (2019). Hematologycal of Jambal Siam (Pangasius hypophthalmus) that using Aeromonas hydrophila Vaccine. Jurnal
Online Mahasiswa Fakultas Perikanan dan Ilmu Kelautan, 6(1): 1-15

Siregar, M., M. Riauwaty, dan I. lukistyowati. (2020). Red Blood Cells of the Siamese Jambal (Pangasius hypophthalmus) Feed Containing HydroVac Vaccine. Jurnal Online Mahasiswa Fakultas Perikanan dan Ilmu Kelautan, 7(1): 113

Sukenda., T. Sumiati, S. Nuryati, A.M. Lusiastuti, D. Hidayatullah. (2017). Specific Immune Response Kinetics and Mortality Patterns of Tilapia Oreochromis niloticus on Post-Cocktail Vaccination Period against the Infection of Aeromonas hydrophila and Streptococcus agalactiae. OmniAkuatika, 13(2): 6-15

Sukenda., T.R. Febriansyah, dan S. Nuryati. (2014). Efikasi Vaksin Sel Utuh Streptococcus agalactiae pada Ikan Nila Oreochromis sp. melalui Perendaman. Jurnal Akuakultur Indonesia, 13(1): 83-93.

Sumiati, T., Taukhid, dan A.M. Lusiastuti. (2019). Evaluasi Standar Kualitas Vaksin HydroVac untuk Pencegahan Penyakit Motile Aeromonads Septicemia (MAS) pada Ikan Lele Afrika (Clarias sp.). Media Akuakultur, 14 (1): 41-47

Syawal, H dan Y.I. Siregar. (2010). Imunisasi Ikan Jambal Siam dengan Vaksin Ichthyopththirius multifiliis. Jurnal Veteriner, 11(3): 163-167

Tamba, J.M., H. Syawal dan I. Lukistyowati. (2021). Idetification of Pathogenic Bacteria from Strepid Catfish (Pangasionodon hypophthalmus) Kept in Aquaculture Ponds. Jurnal Perikanan dan Kelautan, 26(1):40-46

Thiyagarajan, P., A.L. Bhavani, M.G. Ebbie, and G. Chandra. 2014. A study on the Control of Aeromonas hydrophila Infection in the Catfish by Medicinal Plants. Sch. Acad. J. Biosci., 2(2): 144150

Tizard, I. R. (1988). Pengantar Imunologi Veteriner. Ed. 2. Penerbit Universitas Airlangga. Surabaya. $497 \mathrm{hlm}$

Triyaningsih., Sarjito, dan S.B. Prayitno. (2014). Patogenitas Aeromonas hydrophila yang diisolasi dari Lele Dumbo (Clarias gariepinus) yang 
Berasal Boyolali. Journal of Aquaculture Management and Technology, 3(2): 11-17

Utami, D.T., S.B. Prayitno, dan S. Hastuti. (2013). Gambaran Parameter Hematologis pada Ikan Nila (Oreochromis niloticus) yang Diberi Vaksin DNA Streptococcus iniae dengan Dosis Berbeda. Journal of
Aquaculture Management and Technology, 2(4): 7-20.

Wibawa, M.B. (2010). Uji Efesiensi dan Efektifitas Vaksin HydroVac untuk Penanggulangan Infeksi Aeromonas hydrophila pada Ikan Lele dumbo (Clarias gariepinus). Skripsi. Fakultas Perikanan dan Ilmu Kelautan. Institut Pertanian Bogor. 56 hlm 